\title{
Димка Савова
}

Sofia University of St. Kliment Ohridski

dimkasav@abv.bg

\section{ЧЛЕНУВАНЕТО НА ИМЕНАТА В БЪЛГАРСКИЯ ЕЗИК ВЪВ ФУНКЦИОНАЛНА ПЕРСПЕКТИВА (ИДЕИ ЗА ПРЕПОДАВАНЕТО МУ НА ЧУЖДЕСТРАННИ СТУДЕНТИ БЪЛГАРИСТИ)}

Като едно от най-сложните явления в граматиката на българския език членуването заслужава по-специално внимание при разглеждането на методически стратегии за преподаването на българския език като чужд ${ }^{1}$. Най-напред изниква въпросът на коя степен от овладяването на българския език би трябвало то да бъде изучавано. От една страна, членуването е толкова сложно явление (не само от теоретична, но и от чисто практическа гледна точка), че е логично изучаването му да се отложи за един по-късен етап. Освен това, фактът, че толкова други езици не го познават, предполага, че комуникацията може да бъде успешна и без неговото пълно овладяване, и ние на практика при някои чужденци, живеещи от години в България, наблюдаваме именно това.

От друга страна обаче, в методиките се прилага и „спиралообразното” преподаване на по-сложните граматически явления - на по-ранен етап явлението се представя съвсем опростено, на по-късен етап се преговаря наученото и към него се добавят нови специфики и т.н., като в случая с членуването, именно заради неговата сложност, вероятно по-успешна би била тази стратегия. Това означава още на ранния етап, когато студентите се запознават с формалните особености и разпределението на формите за членуване според рода, числото и граматическата категория на имената, да се пристьпи и към преподаването на най-фреквентните и най-лесни за разпознаване видове употреба на членуваните форми.

Друг важен въпрос във връзка с членуването в българския език възниква при съставянето на списък с позиции в изказването, които имат връзка с членуването. Този списък би могъл да се изработи на базата на постигнато-

1 За осветляването му от методическа гледна точка, наред с други релевантни езикови явления, вж.напр. в БЕЧ 1981, при Петрова 1997, Сотиров 2018 и др 
то в теоретичното осмисляне на членуването в българистичната литература (очертаването на връзката му с отделни релевантни логически и семантични категории, със синтактичната и лексикалната семантика, с комуникативната перспектива на изречението, с прагматическото ниво на изказването - вж. в библиографията по-долу: Иванчев 1957; Стоянов 1959; Иванчев 1967, Иванчев 1968; Стоянов 1980; Гинина 1980; Станков 1987; Шамрай 1987; Зидарова 2004, Буров 2004 и др.). Но би могло да се подходи и от една практическа страна на въпроса - от случаите в практиката на употреба на членуваните форми. В този доклад е избран вторият подход, като списъкът с позиции във връзка с членуването е съставен на базата на наблюдения върху практическата му употреба в разговорния език и в по-елементарните текстове. Подобен е подходът и в практическата граматика на българския език за поляци на В. Малджиева [Малджиева 2015], където авторката представя интересна систематизация на категорията определеност / неопределеност, поделена на случаи на възможно (не)членуване, на задължително членуване и на задължителна употреба без членуване.

В началото на усвояването на списъка с позиции, свързани с членуването, трябва да се подчертаят три основни момента. На първо място, трябва да се посочи, че правилата, предложени за усвояване, нямат стопроцентово реализиране в практиката, защото самата употреба на членуваните форми е по-сложна и по-чувствителна към контекста на позицията. Освен това трябва да се изтькне, че предложените правила имат различна „сила” и че често в една позиция се стига до „сблъсък” на две правила, от които трябва да изберем по-силното и да се съобразим с него (вж. за това по-долу). Третият основен момент е свързан с формалната гледна точка към членуването - трябва да се разясни на студентите, че когато съществителното е „обраснало” със свои съгласувани определения, задължително се членува само първата дума в израза.

Във връзка със стремежа членуването да бъде представено на чуждестранните студенти поетапно (,спираловидно”), в доклада откроените позиции са подредени според тяхната сложност, но и според тяхната фреквентност в речта в реда, в който биха могли да се преподават.

1. Първата позиция е функцията на подлог в изречението, който се намира ПРЕД своето сказуемо (макар и не задължително в самото начало на изречението). При тази позиция се изтъква, че ПО-ЧЕСТО такъв подлог е членуван, напр.: Студеното време ни развали настроението. Тази позиция се откроява във връзка с добре известната закономерност подлогът да спада по-често към темата в изречението, която пък се разполага при неутрален словоред пред ремата. В позициите, които се разглеждат по-късно, включвам и типичния модел за изказвания с обратен на посочения тук словоред (за него ще стане дума по-нататьк). Разглежданата тук позиция може да се представи за възприемане и усвояване с упражнение още при преподаването на първите съществителни и глаголи и след това винаги да се коригира, ако е неправилно оформена, за да се автоматизира навикът. Това е нужно, защото тази употреба е една от най-фреквентните. 
2. Също на най-ранния етап може да се усвои позицията, свързана със семантиката на конкретно място, която изисква членуване: Книгите са на мacama. Хубаво е тя да се представи в началото, защото точно в първите уроци се изучават пространствените отношения. На един по-късен етап е добре да се направи опит да се обясни разликата между споменатата семантика на различни съществителни като конкретни локализатори и семантиката на същите съществителни, които не означават конкретни локализатори, а са в изрази с абстрактно значение и нечленувани, от типа на: (имам) на крака - (правя нещо) на крак; седя на масата - седя с някого на маса; лежа на плажа-отивам на плаж (макар че тук може в променен контекст да се използва и отивам на плажа - да се обясни разликата, свързана със значението на единичност, което по-долу изтъквам в отделна позиция).

3. Третата позиция, която е подходяща за най-ранния етап, е употребата след глаголите има / няма на нечленувани думи и изрази: Той има хубава кола; В гората има диви животни. При това е хубаво да се направи опит да се обяснят двата характерни за този глагол вида употреби: в лична форма и като безличен (важно е да се обясни добре безличната употреба на глагола, защото често в славянските езици в такава позиция се използва глагольт съм срещу българското безлично има).

4. Макар че темата за различните средства за изразяване на отношенията на притежание е доста сложна, налага се да се покаже отношението на основните от тези средства с членуването, защото от гледна точка на лексиката е наложително отношенията в семейството да се вземат още в началото на курса (употребата на лексиката за роднинските връзки е тясно свързана в българския език с винаги експлицираните отношения на притежание: майка ми, синът ти и т.н.). Затова при тази позиция синтагмите за изразяване на отношения на притежание са разделени най-напред на синтагми с притежателно местоимение и синтагми от две съществителни, свързани с предлога на. Основно място се отделя на кратката форма на притежателното местоимение, като синтагмите се разделят според семантиката на главното съществително: дали означава роднинска връзка или нещо друго, а след това - според това дали съществителното, което означава роднинска връзка, е в единствено или в множествено число. Привеждат се, съответно, всички изключения, които, противно на правилото, се членуват в единствено число. След това накратко се изтъква, че в синтагми с пълната форма на притежателното местоимение то е членувано, и се припомня, че се членува винаги първата дума, каквато е обикновено тази форма (твоята братовчедка, срв. неправилното при стилистично немаркирано изказване: братовчедката твоя). Накрая се отбелязва задължителното членуване, независимо от числото, на съществителни, които не означават роднински връзки, когато са употребени с краткото притежателно местоимение (чантата ти, палтото му). Упражненията, които се правят тук, са полезни не само за граматиката, но и за усвояването на лексемите от темата за роднинските връзки. 
След това вниманието се спира върху притежателните синтагми, състоящи се от две съществителни, свързани с предлога на. Тук препоръчвам на студентите да членуват главното съществително, ако притежателят, изразен чрез подчиненото съществително, е конкретен (т.е. с конкретна референция), напр. косата на момичето, обувките на майка ми.

След позицията за синтагми със значение на притежание, където основно се разглеждат синтагми с притежателното местоимение, се откроява и позицията с всички други видове местоимения, където членуването не се допуска. Отбелязвам същото правило и с числителното един, една, едно (но на по-късен етап разглеждаме позицията при противопоставяне, когато групата с един трябва да се членува: единият..., а другият ...).

5. Също на един начален етап се откроява позицията на предикатив, в която съществителното или именната синтагма са най-често нечленувани: Аз съм добър ученик. Хората са разумни същества.

6. След това обаче идва правилото за определително изречение, въведено от относителното местоимение който, която, което, които, защото това правило може да противоречи на горното. При обяснението на тази позиция прокарваме заедно със студентите на базата на примери разлика между определителните рестриктивни и определителните нерестриктивни изречения. Разликата не е толкова лесна за възприемане, затова предлагам един тест за разпознаване на двата вида - чрез замяна с местоименията този и такъв, напр. в изказването За къщцата, която вчера ти показах, мечтаят много хора замяна би било изречението 3 а мази къщза мечтаят много хора. От друга страна, ако имаме изказване За къща, която има тераса и двор, мечтаят много хора, ще имаме замяна с местоимението такъв: За такава къща мечтаят много хора.

Накрая тази позиция се свързва с предходната за предикатива, за да получи обяснение въпросът кога предикативът трябва все пак да бъде членуван (напр. Това е къщата (тази) / къща (такава), за която мечтаят много хора.

7. При граматическата тема за сравнителните степени се открояват позициите, свързани със сравнението и сравнителните степени. Отбелязва се, че в израз за сравнение между две съществителни по някакъв признак и двете са членувани: Кафето е по-силно от чая. При превъзходната степен заради значението на уникалност на тази степен именната група в тази позиция по-често също се членува: най-хубавото извете.

8. На един по-късен етап, когато първоначално натрупаният лексикален фонд започва да се обогатява с вариативни средства и студентите се запознават с възможности за аналитично изказване на глаголния предикат, идва ред на правилото, че съществителното в аналитичния израз не се членува: вземам участие = участвам.

9. Макар че в българската граматика говорим за определителен член, позицията, свързана с определеност / неопределеност на именната фраза, не е лесна за усвояване, затова е добре тя да бъде взета на един по-късен етап от обучението. По-проблемното ѝ усвояване се дължи може би не само на по-слож- 
ната семантика на тази позиция, но и на неяснотата, сьдържаща се в термина определеност на дадено понятие - обикновено студентите са склонни да приписват на всички членувани изрази това определение, без да могат да формулират в какъв смисъл е определена дадена конкретна синтагма.

За да бъде обяснена тази позиция, може да се започне с това, че с неопределеност се характеризира дадено понятие, което се появява за прьв път в текста (или разговора), и да се отбележи, че типичното място на това понятие е СЛЕД сказуемото. Добре е да се отбележи, че допълнението, което може да бъде неопределено, но може да бъде и определено, по правило при неутрален словоред се намира след сказуемото, напр.: Вчера видях в стаята (едно) ново момче. Докато подлогът се намира по правило там именно когато е неопределен, напр.: На пътя излезе селянин, който яздеше магаре; Посред нощ ме събуди тиха песен. При неопределените понятия трябва да се обърне вниманието на студентите върху употребата на числителното един във функцията на неопределителен член (но като се изтькне и нейната незадължителност).

След като се въведѐ неопределеността, по-лесно е да се обясни и определеността на дадено понятие - като резултат от три обстоятелства. В първия случай дадено понятие става определено, след като веднъж вече е въведено в текста (разговора). Във втория случай конкретното понятие може да не е било въведено преди това в текста, но да е част от фрейма на някакво вече въведено понятие. В третия случай името или именната фраза може да е кореферентна на вече въведено понятие. И в трите случая думата или синтагмата се възприемат от говорещия като определени и съответно се членуват. Пример за първия случай може да бъде следният текст: Вчера в нашия клас дойде ново момче. Постепенно класната стая се напълни с ученици. Всички се запознаха с новото момче. Примери за втория и третия случай ще бъдат съответно: за втория - Отидохме в парка на разходка. Алеите бяха мокри, детската площцака беше празна, люлките бяха счупени; за третия случай: На вгъла стоеше съученикът на моя син, Петьр. Момчето явно чакаше някого.

10. Когато при лексиката се упражняват предлозите, могат да се вземат и три по-фреквентни позиции на членуване, свързани с предлозите в българския език:

А) в изрази с предлога през, които имат темпорално значение, названията на месеците никога не се членуват (през декември), а названията на сезоните и на други периоди винаги се членуват (през пролетта, през нощмта, през годината). Тук, за да бъде по-добре запомнено това правило, се прави сравнение със значението на израза с предлога през, но с нечленувано съществително (през нощ).

Б) втората позиция е свързана с предлога $c$, употребен в израз със значение на обстоятелствено пояснение за начин (как? с какво?). Отбелязва се, че когато съществителното има абстрактно значение, то не се членува: $\boldsymbol{C} \boldsymbol{p} \boldsymbol{a}$ дост ще дойда; Погледна ме с надежда. Когато пък съществителното има 
конкретно значение, а изразът има значение на средство, с което се извършва действието, се прилага горното правило - в зависимост от позицията за определеност / неопределеност на съществителното, напр.: Написах писмото с червената химикалка/с червена химикалка.

В) в израз с предлога от, който означава член/ част от някакво множество, това множество се възприема като определено и съществителното, с което то е означено, се членува: никой от студентите.

11. По-сложна за възприемане е и позицията, в която някакво ИЗВЕСТ$\mathrm{HO}$ за говорещия понятие в даден израз се тълкува от него като ЕДИНСТВЕНО на дадено място или в даден момент (това понятие може да не е единствено, но говорещият да игнорира другите), напр.: Cъcедъm ми каза, че Мария се е върнала (говорещият може да има няколко съседи, но да си общува само с един или на етажа да има само един) - Eдин съсед ми каза, че Мария се е върнала.

Освен тези правила, които се очертават за съществителните както в единствено, така и в множествено число, би трябвало да се изтькнат и още поне две правила за съществителните в множествено число.

12. Първото засяга значението на членуваното съществително в множествено число, когато то означава включеност на всички членове от дадено

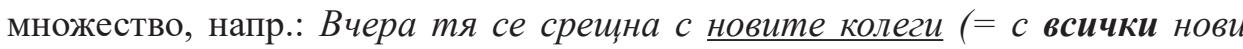
колеги).

13. Второто правило засяга съществителните в множествено число, които нямат конкретна референция, а означават род (вид) живи същества, растения, природни явления и под., и трябва да се членуват, напр.: Вчера госпожата ни чете разказ за пингвините. Тук обаче би трябвало да се обърне внимание на една фреквентна употреба, при която това правило се «сбльсква» с правилото за нечленуваните съществителни в позиция на предикатив, което е по-силно от разглежданото тук правило, срв.: Животните, които виждате на снимката, са пингвини. Накрая това родово значение трябва да се разграничи от употребата с конкретна референция, която не се подчинява на това правило, напр.: На ледената повърхност имаше налягали пингвини. Пингвините си почиваха от дългия преход.

И така, в този доклад бяха предложени някои идеи за преподаване на темата за членуването в българския език. Беше направен подбор на по-фреквентните позиции на членуване в нашата реч, разпределени според тяхната сложност, но беше изтъкната относителната валидност на очертаните правила и възможността те да влизат в „сблъсък“. След всяка позиция на студентите се предлагат съответни упражнения, а може да им се предложи постепенно сами да попълват списъка с отделните позиции, докато накрая получат в списька си цялата тема за членуването. 


\title{
Библиография
}

БЕЧ (1981), Български език за чужденци - актуални проблеми на обучението (отг.ред. Хр. Първев), ИЧС - ФСлФ, София.

Буров С. (2004), Познанието в езика на българите. Граматично изследване на концептуалната категоризачия на предметността, Велико Тьрново.

Гинина С. (1980), Категорията определеност/неопределеност на имената в българския език и въпросите на актуалното членение на изречението, „Sbornik pracy Filozoficke fakulty Brnenske university" A 28, c. 149-160.

Зидарова В. (2004), Семантика, прагматика и типология на детерминацията в съвременния български език, [в:] Славистика, Пловдив, с. 73-81.

Иванчев С. (1957), Наблюдения върху употребата на члена в българския език, Български език, т. 7, кн.6, с. 499-524.

Иванчев С. (1967), Към въпроса за членуването на генерично употребения подлог, „Език и литература“", т. 22, кн. 4, с. 62-64.

Иванчев С. (1968), Проблеми на актуалното членение на изречението, „Славянска филология“", т. 10 , с. $39-54$.

Малджиева В. (2015), Praktyczna gramatyka języka butgarskiego dla Polaków, Torun.

Петрова С. (1997), Българският език като чужд (история и методика), София.

Сотиров П. (2018), „Новият лингвистичен ред“ в България и преподаването на българския език в чужбина, „Езиков свят“, т. 16, кн. 1, с. 67-73.

Станков В. (1987), За семантичния инвариант на определителния член в българския език, „Български език“, т. XXXVII, кн.1-2, с. 71-76.

Стоянов С. (1959), Употреба и значение на определителния член в съвременния български книжовен език, София.

Стоянов С. (1980), Граматическата категория определеност в българския език (Членуване на имената), София.

Шамрай Т. (1987), Референция и семантична интерпретация на изречението с оглед на категорията определеност/неопределеност. - Втори международен конгрес по българистика. София, 23 май-3 юни 1986 г. Доклади 3. Съвременен български език. БАН, София.

\section{Димка Савова}

\section{THE ARTICLE OF THE BULGARIAN NOUNS FROM A FUNCTIONAL PERSPECTIVE (SUGGESTIONS FOR TEACHING FOREIGN STUDENTS)}

\author{
(Summary)
}

The paper discusses the practical dimensions of one of the most important and most complex questions in teaching the Bulgarian language to foreigners, which is the article. The author offers a model for teaching the article that includes ten major cases of its usage and is based on personal experience as a Bulgarian language lecturer. The paper's aim is to suggest new ideas in teaching Bulgarian to foreigners.

Key words: article, training methodology, Bulgarian for foreigners 